Case Reports

\title{
Violence on Social Media: An Exploration into the Online Expressions of Adolescents from Marginalized Areas of Greater Buenos Aires
}

\author{
${ }^{1}$ Joaquín Walter Linne and ${ }^{2}$ María Florencia Angilletta \\ ${ }^{1}$ PhD in Social Sciences. Adjunct Researcher of the CONICET [National Scientific and Technical Research Council] based at \\ the Gino Germani Research Institute, UBA [Universidad de Buenos Aires]. Adjunct Professor, Universidad Nacional de Lanús, \\ Buenos Aires, Argentina \\ ${ }^{2}$ PhD student in Gender Studies. Doctoral Fellowship from CONICET based at the Instituto de Filología y Literaturas \\ Hispánicas, School of Philosophy and Literature, UBA, Buenos Aires, Argentina
}

Article history

Received: 30-04-2020

Revised: $19-05-2020$

Accepted: 29-05-2020

Corresponding Author: Joaquín Walter Linne $\mathrm{PhD}$ in Social Sciences. Adjunct Researcher of the CONICET [National Scientific and Technical Research Council] based at the Gino Germani Research Institute, UBA [Universidad de Buenos Aires]. Adjunct Professor, Universidad Nacional de Lanús, Buenos Aires, Argentina Email: joaquinlinne@gmail.com

\begin{abstract}
This paper explores the online expressions of violence perpetrated or experienced by adolescents from marginalized areas of Greater Buenos Aires, Argentina. Four specific events-threats, "bondis" [fights], cyberbullying and grief-were examined using a qualitative methodology consisting of 20 in-depth interviews and 3,000 virtual observations of Facebook profiles. Among the main findings, most expressions of violence were found to be part of an offline-online dynamic. Based on the empirical evidence provided herein, it can be affirmed that these adolescents' expressions of violence develop around the culture of "aguante" [fierce loyalty]. This paper ponders whether on the "Like" platform, these expressions are implicitly utilitarian to the social network or, on the contrary, they enable displacements and meaningful reappropriations on the part of users. Ultimately, it poses new questions about the use of these tools by adolescents from marginalized areas and sets out to delve into the approaches used to examine these phenomena in all their complexity.
\end{abstract}

Keywords: Adolescents, Social Networking, Violence, Suburban Population, Argentina

\section{Introduction}

By reviewing the literature available on this subjectmatter, it becomes clear that violence does not allow for a univocal definition. Indeed, socio-historical changes show disputes within societies over the definition of violence-related phenomena, including, among others, material conditions, symbolic practices and the use of physical force. Without disregarding the magnitude of these debates, violence may be defined here from a biopolitical perspective as a productive practice-in the sense of a practice generator-rather than merely as a restrictive practice. Foucault (2002a; 2002b) holds that, in modern societies, traditionally coercive, negative strategies are integrated into a more complex technology of what he calls "biopolitics" to produce "docile bodies." "Biopower" is no longer solely centered on the severity of "punishment;" instead, it implies diverse "surveillance" systems to control bodies. In his analysis on power and violence, Foucault states that this is a kind of power that operates through production, intensification and administration: "It is no longer a matter of bringing death into play in the field of sovereignty, but of distributing the living in the domain of value and utility (Foucault, 2002a p.136).

Already from its own genealogy, modernity has been marked by different forms of violence. The complex relationships among the State, the law and violence constitute a series of modulations that enable the resignification of modernity's self-perception within the context of the bourgeois revolutions. In this regard, the fact that the French Revolution was one of the foundational milestones of the Contemporary Age is symptomatic, especially given that its motto called for literally "beheading the monarchy." From an innovative perspective, Benjamin (1991) proposed to review the conflicting connection between violence and democratic order. Moreover, as mentioned above, Foucault (2002b) studied the links between violence and power and showed that these relationships cannot be conceptualized in a dual, hierarchical manner only, but rather as multifaceted, central nodes within the so-called "micropolitics." 
In the 20th century, limit-experiences such as World Wars I and II and the ensuing armed conflicts brought about new deliberations on violence. Authors such as Sloterdijk (2000) and Rancière (1996) highlight this "crisis of Humanism" and its effects regarding global violence issues such as terrorism, urban poverty, the refugee crisis and gender-based violence. Furthermore, Isla and Míguez (2011) along with Spinelli et al. (2005) and Tonkonoff (2014) agree that violence is a social and historical construct and as such, its practices change in accordance with the negotiations and consensuses established within each society. Although this is by no means a fully comprehensive overview, it should be noted at least that every violence-related observation must be necessarily analyzed within the broader field of democratic, institutional and legal life in order to avoid a stigmatizing interpretation of a social group.

One contemporary phenomenon most affecting the global population is urban violence, defined here as the specific set of violent actions that take place in cities, altering their social fabric (Imbusch et al., 2011). Some typical examples of violence in megalopolises, capital cities and metropolises include theft and murder, as well as street fights, criminal offenses, tax evasion, traffic accidents and disturbances in soccer stadiums.

In particular, socially vulnerable groups (Auyero and Berti, 2013) are affected by the type of violence connected with socioeconomic difficulties, such as lack of stable employment or of access to basic social services. In Argentina, neighborhoods with such characteristics are usually called "villas de emergencia," "villas miseria," or "asentamientos urbanos precarios" [slums, shantytowns, or ramshackle settlements]. These neighborhoods are also referred to as "urban margins (Auyero and Berti, 2013; Kessler and Jóvenes, 2013), as they are territories segregated from the more developed areas. Ultimately, these are usually isolated areas, with poor access to social, health care and transportation services (INDEC, 2010). Wacquant (2007), who researches the social stratification phenomenon affecting these groups, uses the term "urban ghettofication processes" to define the progressive social isolation experienced by these communities.

In Argentina, Auyero et al. (2014), Di Leo (2013), Isla and Míguez (2011), Kessler and Jóvenes (2013), Spinelli et al. (2005) and Tonkonoff (2014) analyze the different types of violence displayed in recent years in the urban margins of the Metropolitan Area of Buenos Aires (AMBA) [Área Metropolitana de Buenos Aires] ${ }^{[\mathrm{a}]}$ : First, there is an interpersonal type of violence arising from confrontations among neighbors, family members or peers; second, there is violence related to criminal activities, social issues and the punitive action of the State. These authors assert that violence is usually one of the main concerns of the socially vulnerable inhabitants of AMBA.

Even when face-to-face violence among socially vulnerable groups has been studied, the incidence of the widespread use of Information and Communications Technologies (ICT) among youth in AMBA requires broadening the scope of analysis even further to include emerging phenomena, which are examined in this paper. Morduchowicz (2012) contends that adolescent socialization takes place in an offline-online continuum. Similarly, it can be concluded that the violence they experience occurs in a comparable context. Thus, fights, theft, social stigmatization, school segregation and gender-based violence are interconnected with phenomena arising from the mass use of ICTs.

There has been a significant amount of research on violence recently in Latin America (Imbusch et al., 2011; Misse, 2010; Valdivia and González, 2014) and in Argentina (Isla and Míguez, 2011; Spinelli et al., 2005; Tonkonoff, 2014; Auyero and Berti, 2013; Kessler and Jóvenes, 2013; Auyero et al., 2014; Di Leo, 2013; Duschatsky, 2011). In particular, the literature dealing with expressions of violence in "social networking websites" was reviewed, revealing only a scarce number of studies on adolescents from working-class sectors, given that most studies are limited to middle-class youth Smith et al. (2008; Del Río Pérez et al., 2010; Buelga and Pons, 2012; Wendt and Lisboa, 2013; Menay-López and de la Fuente-Mella, 2014). On the same note, in an effort to contribute to the understanding of this complex contemporary topic, this paper focuses on the online expressions of violence posted on Facebook by workingclass youth in AMBA.

Adolescence is a central identity configuration stage during which exploratory practices (Aisenson et al., 2006; Krauskopf, 2007) are essential. As a result of the mass use of ICTs and their integration into the daily lives of most adolescents, a significant portion of this identity configuration stage and these exploratory practices usually takes place in connection with the profiles created by these youngsters on Facebook (Linne, 2015). This is then the platform chosen for this analysis, as it has become the largest social networking website globally and, for many adolescents, it is synonymous with the Internet, as this is where they carry out most of their online communications or leisure activities (Urresti et al., 2015). Therefore, this platform becomes a privileged setting for looking into this population's practices.

On the basis of the fieldwork conducted, two lines of exploratory research studies were developed in relation to the expressions of violence displayed by these adolescents on Facebook: The first one refers to the violent practices of users in an offline-online circuit; the second one revolves around the practices that enable users to express and resignify the violence they 
experience within that same circuit. The former encompasses threats, "bondis" [confrontations involving online and offline practices, also spelled "bondys"] and cyberbullying. The latter explores ways to cope with grief. Both dimensions give rise to questions as to whether Facebook is merely a device that reproduces these phenomena or it empowers these populations in light of the violence they suffer.

\section{Methodology}

This is a qualitative exploratory research (Linne, 2015). It is based on a non-probability sample of adolescents living in AMBA who were recruited through a snowball sampling technique. Twenty in-depth interviews, running for approximately one hour, were conducted in school or digital inclusion center classrooms ${ }^{[\mathrm{b}]}$, along with face-to-face observations in schools, Internet cafés, the street and digital inclusion centers.

The subject of study was constructed at the intersection of two variables: Age and social class. Some methodological precautions were taken in order to avoid the homogenization of the study subject from an androcentric (Elizalde, 2015) perspective, thus capturing the different modulations observed in men and women. As to the first variable, within the category of youth, defined by various authors as a social construct (Krauskopf, 2007; Margulis et al., 2007), this research study focuses on adolescent boys and girls aged 13 to 18 . As for the second variable, this paper is concerned with the study of adolescents from socially vulnerable areas.

Several research studies (Isla and Míguez, 2011; Auyero and Berti, 2013; INDEC, 2010; Margulis et al., 2007) agree, albeit with some nuances, on defining these groups as communities that live in unstable socioeconomic conditions in neighborhoods that lack basic social services, all of which leads them to become socially isolated from the metropolis they belong to or that can be found in close proximity. On the basis of the analytical productivity of these studies and data collected by the Argentine Institute of Statistics and Censuses (INDEC) [Instituto Nacional de Estadística y Censos] (INDEC, 2010), this research study sets out to define these social groups as working-class groups and subclassify them as either integrated or marginalized. On the one hand, distinctions need to be made within this group. On the other hand, this subclassification also relates to the search for greater sociological precision in describing these social groups in order to enhance the possibilities of transference. Far from intending to increase the stigmatization suffered by these adolescents, this paper seeks to contribute to the state of the art and propose new and useful research tools for optimizing public policies aimed at this population.
In contrast with the past three decades and despite the State's greater role in socioeconomic assistance and transfer of technological resources to this socially vulnerable groups through social programs such as Asignación Universal por Hijo [Universal Child Allowance], Programa Conectar Igualdad [Connect Equality Program], Programa Jóvenes con Más y Mejor Trabajo [Program for Youth with More and Better Jobs] and Plan Fines [Goals Plan], ${ }^{[\mathrm{c}]}$ there are still numerous adolescents from these areas facing poor living conditions for which the State needs to provide further solutions. Given their higher level of involvement in the education system, the formal labor market and the health care system, the integrated working-class communities from AMBA usually benefit the most from these public policies. On the contrary, the marginalized working-class communities have a less stable and more conflicting contact with these programs and, are therefore often ambiguously affected by these public policies although they are the ones most in need of the State's direct involvement. Indeed, the communities defined herein as marginalized working-class groups have to deal with the most extreme and appalling living conditions: their parents are unemployed or underemployed and poorly qualified; they live in precarious homes and neighborhoods, attend school irregularly and running into many difficulties, or drop out for a number of reasons.

One of the greatest challenges for research in social sciences is how to approach these vulnerable population groups, which maintain an intermittent relationship with governmental institutions. In this regard, as a social platform, Facebook provides researchers with a methodological strategy that paves the way for doing fieldwork with these adolescents. One of the tools developed to carry out the study was the creation and management of an ad hoc Facebook profile. This observation method was created to study adolescents online, based on recommendations from several research studies that use digital ethnography to understand a population that consider these media essential (Wendt and Lisboa, 2013; Menay-López and de la Fuente-Mella, 2014; Hine, 2012; Boyd, 2014). While working as a voluntary teacher in a center for social inclusion located in the southern area of AMBA, a fellow researcher and community leader commented that he used Facebook to "monitor" adolescents in the area. This proved to be a valuable resource to move this study forward; therefore, a profile was created for analytical purposes and working-class adolescents who were mutual Facebook contacts were added. The ad hoc profile was only used to observe, write comments and "like" some posts.

This Facebook account, which had 3,000 contacts at the time of the study, made it possible to explore the ways in which adolescents portray themselves and interact with others, as well as the strategies and 
resources they use for designing and updating their profiles on this social media platform. This experimental stage, developed between 2013 and 2014, proved to be one of the most important aspects of the fieldwork, considering the profuse amount of archival material collected, catalogued and analyzed. Folders with different names were created to organize the images and personal texts gathered, making the analytic proposition of violence-related phenomena possible. Although several of the classic stages of investigation were actively followed, the ethnographic-digital aspects of the research work provided elements of analysis about significant activities of adolescents that were not always easy to find in situ. This cataloguing technique made it possible to detect, over three years of online observation, the recurring appearance of certain expressions such as "aguante" [fierce loyalty or endurance], "bardeos" [the act of making trouble and harassing others], or "pararse de manos" [defending oneself or showing no fear against an ensuing fight $]{ }^{[\mathrm{d}]}$

For ethical reasons, consent was obtained from the interviewees and no record of their personal data was kept. It should be mentioned that Facebook is a social networking website that operates under terms and policies similar to those of most sites of its kind: its use is not restricted to anyone over 13 years old; any person this age or older is entitled to use the platform and all users enter into an agreement with Facebook whereby they agree that their posts will be available online. To protect these adolescents' identities, generic labels were used for each quoted statement. In the interview excerpts and Facebook screenshot transcriptions, only the user's sex and age are specified.

\section{Results}

\section{Threats}

The fieldwork revealed that one of the most recurring types of online violence expressions among the sampled adolescents is the one that involves a suggestion, possibility, or warning about future acts of violence. These types of expressions are herein referred to as "threats." Often times, the purpose of these practices is to instill fear in the recipient or even deter him or her, either directly or indirectly, from carrying out certain actions. Although these threats are typically aimed at violently warning an individual to do or refrain from doing something, after observing these practices it is clear that the threats are not always directed against a specified group and the real intention is for the profile of the author of the threats to arouse respect amongst his or her peers.

At this point, it is necessary to reconsider the concept of the "aguante" (Alabarces and Rodríguez, 2008) culture, which is central to the universes of meaning of these adolescents from socially vulnerable areas in AMBA. This native term originally evoked certain associations of practices and meanings in connection with the ability to deal with difficult times in the life of one's soccer club, for example, relegations and confrontation with other "barras" [hooligan gangs], or fights within the neighborhood or other institutions (Garriga Zucal, 2005). Later, the "aguante" culture acquired different modulations in connection with the "reviente" culture [social acceptance of harmful habits such as alcohol or drug abuse] and with different ways of exteriorizing one's masculinity and legitimate being. As the cited studies show, for marginalized working-class youth from AMBA, "aguante implies fidelity, support, endurance (Urresti, 2007). In this respect, sometimes instead of being directed against another social media user in particular, the threat fades away into anonymity and its effect can be considered in terms of "aguante," as the user shows his or her ability to resist, to face adversity, to not run away ["arrugar" [e]] and "to be up in arms against anyone" ["pararse de manos ante cualquiera"].

You just type, you silly pillock, but I don't
crap my pants whenever you want we can
fight, haha but we've both already fought
once and you called up all your gang you act
as if you're cool 'cause you know people from
celinna 'pompeya haha I don't give a damn
about that, my problem's with you I know
you're afraid of me [emoticons] so just say
when and we can fight face to face, you rat,
keep your drama for someone else, no one
dares to provoke me, let alone you, so think
about that [emoticon] I'll feel [P]
(Facebook post, user from AMBA)

The above transcription is a post by a teenage girl (16 years old) who threatens another girl and clearly asserts that she is not afraid of a physical confrontation. On the basis of a series of references found in this post, different intersections between the offline and online contexts stand out. First, the author of the threat refers to a shared history between her and the recipient: "We've both already fought once." Second, the mention of "celinna "pompeya" [neighborhoods of AMBA] is a territorial reference to the neighborhoods they feel identified with, which in turn implies a form of "aguante." Finally, by using the expression "face to face" the author states that she is ready for physical confrontation. The threat, implying eventual execution of violence in a face-to-face context, shows that these expressions are often part of an offlineonline continuum. The threat is made online, but the key to its reading lies in the reference to an offline context.

Another common practice among the adolescents in this study consists in posting on their Facebook profile or status fragments of lyrics from songs that, according to them, thematize their living conditions and, at the same time, may serve as threats. This is evidenced by the fact that 
many of these bands' names ${ }^{[f]}$ and lyrics refer to police persecution, imprisonment and drug trafficking or abuse.

*.-

La mafia [a cumbia villera band] keeps playing, bitch \& I'll put it shortly, Don't mess with us girls or your life will get shorter $\$$

[emoticon] (Facebook post, user from AMBA)

This post was written by a teenage girl (16 years old). Míguez (2006) Semán and Vila (2011) and Silba (2012) agree that the lyrics of cumbia villera songs [a popular music genre originated in ramshackle settlements] resonate with these groups as they present daily life narrations in connection with insecurity in the neighborhood and certain activities such as drug use, violent episodes and confrontation with the police, which may include anything from arbitrary inspections and interrogation to repression and "trigger-happy" shootings. In this particular example, it is clear how the teenage girl uses a fragment of a song for self-legitimization and to emphasize that she has enough "aguante" to resist fights and adversity.

The choice of examples mostly involving women was deliberate. From a gender perspective, ${ }^{[g]}$ there is an emerging phenomenon, which consists in women displaying "aguante"-related behaviors which, under a sex/gender, heteronormative system (Rubin, 1975), are traditionally associated with masculinity. The consideration of this dynamic occurring in workingclass groups from a gender perspective evidences a non-hegemonic femininity in connection with "aguante" in bodily and territorial terms and this shows another possible modulation for a new "girls' era (Elizalde, 2015).

However, as shown by other papers (Linne, 2014) as well, these emerging modulations coexist in tension with traditionally masculine practices. One of the analyzed cover photos that was selected by a teenage boy (17 years old) to introduce himself to others showed two guns and the words "I LOVE YOU" written with bullets and, between two boxes full of ammunition, the following phrase below: "But if you betray me, all these will be yours." The apparent love declaration works as a threat for his partner: Love will only be possible if she accepts the proposed power and violence dynamic. The threat effect is complete because it nullifies any chance of negotiation and establishes that only the man is entitled to define betrayal. The threat is also directed at his male peers, because it works as a way of "aguante" legitimization, as understood from a traditional sex/gender perspective, in connection with the asymmetric power relationships that men establish with women.

\begin{abstract}
Many choose these cover photos because they think it pays to show yourself jealous and guarding. They go too far, though some girls are really into that. Many of us want a caring, faithful, super-loyal boyfriend, but boys cross the line and sometimes they get high or drink too much and become violent and that's not cool. (Interview, female, 18 years old)
\end{abstract}

The three selected excerpts are, as a whole, paradigmatic for the analysis of threatening expressions and the production of subjectivity among marginalized working-class adolescents in AMBA. Thus, emerging and traditional gender norms coexist. The last excerpt shows the persistence and even the dangers, of a traditional gender system that links threats and "aguante" to a hegemonic masculinity that prioritizes the actual or potential use of physical force, control and abuse of power. Nevertheless, the first two examples show the possibility of an emerging gender system that extends the value of "aguante" to women, enabling them to explore practices of non-hegemonic femininity.

\section{Bondis}

"Bondi" is the native term used by adolescents of these marginalized working-class groups from AMBA to refer to a fight. It is not merely a synonym for "fight," as it implies a shift from and a construction around this signifier. What is at stake in a "bondi"? Which are the strategies deployed by those who take part in a "bondi"? Unlike threats, "bondis" usually take place between some particular users.

By definition, a "bondi" also encompasses offline and online practices. Sometimes, a "bondi" starts online, it goes viral within the small community of peers and then extends to face-to-face settings such as the neighborhood, the school, or the night club. Other times, a "bondi" starts in offline spaces and continues online, amplifying the initial conflict and bringing in new users who feel touched and get involved in the dispute.

This is for all the silly pillocks! I won't be kind to you or eat crow, why don't you stop fooling around and in any case if you're so great you stand up by yourselves? Why are you getting relatives involved? When it's you who're looking for a fight! You're grownups, man! You already got kids and still act like brats! If all of a sudden Papu knows who he loves and who he doesn't love! That's it. You shouldn't be boasting around \& let's get clear about something: If you have to do something just do it and that's it! Stop boasting on facebook, I'm so pissed off and if you keep talking nonsense I'm gonna get you one by one! Now I'm not in the mood for dealing with any of you idiots! And of 
course I cried for him because I know he loved me! And I loved him too. See ya! No reason why I should be talking about this on Facebooks SYL. (Facebook post, female user from AMBA)

The above transcription was posted by a teenage girl (17 years old) that gives an account of a "bondi" that arose out of a conflict surrounding the end of a romantic relationship and the gossiping among women close to her.

Sometimes 'bondis' start on Facebook. Maybe they start at school, then continue on Facebook and end up on the streets. Many women get into fights when they come out of school over things that happen on Facebook. Rumors about one of them messing around with another girl's boyfriend, for example. (Interview, female, 16 years old)

Facebook is full of boys and girls passing rumors and insults around. They start 'bondis' for whatever reason: If someone was with someone else, or if they said this or that, if someone looked at or dated someone else, they start a row.

(Interview, male, 17 years old)

In these interview excerpts, adolescents mention the problems arising from "chismes" [gossip] and "bardeos" [aggressions]. These conflicts are associated with the monitoring enabled and in some ways stimulated, by a social platform like Facebook, which pushes users to constantly follow their contacts' activities. Furthermore, the frequent "bondis" may also serve as a means to dispute the degree of "aguante" since, in these fights, the honor and prestige of each party are put to a test in relation to their performances based on their endurance and boldness.

- There was a HUGE 'bondy' with the guys from my neighborhood a while ago $x D$ (people from iNTA against the 20) [neighborhoods from AMBA]

They're such thick-heads, man -.- THEY'RE GONNA GET IT TOMORROW and THE BITCH THAT SHOWS UP IS GONNA GET IT TOO, ha. IN ONE GO, TOMORROW WITH THE GIRLS, FULL ON, WE'RE STANDING UP AGAINST AnYONE and EvERYONE WHO GETS INVOLVED in the 'bondy', [emoticon] ;))

And to cap it all, I'm super pissed off with some bitches who were acting as if they were cool, HAHАНАНАНАHA XD they fled off to their neighborhood, PUSSIES, they're so chickenshit, they always run away [emoticon]

(Facebook post, female user from AMBA)
In this transcription, a teenage girl (16 years old) mentions that there was a huge "bondy" among kids from two neighborhoods ("people from Inta against the 20 "). She also states that "they're gonna get it tomorrow \& the bitch that shows up is gonna get it too." Finally, she insinuates that she and the people from her neighborhood are the ones that have the most "aguante" and the others "can't take it" and always "run away." These types of posts suggest an emerging gender order in which women from marginalized working-class areas can also fight and show "aguante." Considering the meaning they give to those words, this implies the subjective legitimization of using their bodies to protect their honor and territory. This post received 30 "likes" and tens of comments.

\section{Cyberbullying}

Bullying, an English loan word used in Argentina, refers to harassment inflicted on an individual by his or her classmates or peers. The term came to prominence on the media agenda and has been especially associated with adolescence and the school setting. The term encompasses any hostile action or communication that a group of adolescents directs at another adolescent, from hitting or threatening someone to stealing his or her belongings, writing aggressive messages or refraining from speaking to him or her (Willard, 2005). In the age of social networking websites, the term cyberbullying (also known as "cyber-harassment" or "online harassment"), meaning bullying perpetrated through digital media, has become increasingly common. According to Willard (2005), cyberbullying may be simply defined as the act of sending or posting content (text or images) over the Internet or a mobile phone with the intention of harming someone else. Mason (2008) adds that cyberbullying may be carried out by an individual or a group and, in either case, in a deliberate and repetitive fashion. In other words, cyberbullying involves sending aggressive messages, posting messages that spread rumors or a group's decision of not interacting with a certain profile. On many occasions, bullying and cyberbullying should be construed as two manifestations of the same conflict that mutually backfeed each other. While the definitions of these phenomena offered by the literature are different, there is consensus that they involve aggression, repetition and power inequality (Willard, 2005). The ubiquity and capability of ICTs to reach significantly larger audiences is a specific feature of cyberbullying in comparison to other types of harassment (Smith et al., 2008). In this regard, Kowalski et al. (2008) state that, according to the adolescents consulted, anonymity tends to make cyberbullying easier, because the bully has more possibilities of going unpunished. 
Thus, this paper posits that all the expressions of violence that a group of users direct at a single user from the social media platform should be grouped under the abovementioned concept of cyberbullying. It is worth mentioning that, in this case, unlike the native word "bondi," an English term made popular by the mass media is used in Argentina, quite differently from the previous notion. Furthermore, it should be clarified that this problem does not only affect adolescents or marginalized working-class areas, since it is also observed in other social areas and age groups, although worldwide cyberbullying cases are still more commonly found among adolescents (Del Río Pérez et al., 2010; Kowalski et al., 2008; Bottino et al., 2015).

No way i'm wussing out about the stuff they put on the walls of my school, but if you are so cool-'cause $i$ know it was a jelalous fucker the one who did it-why don't you sign your names? 'cause you're scared because you know i'll be up in arms, $i$ ain't crapping my pants against anyone no matter if $i$ win or lose you can suck my cunt i fight and that's it! Idiots sign your names (; you think you're cool? Haahahahhahahahaha hairy birdies take a shower and then we'll talk you can't even tie your shoelaces. You do that 'cause you are a jealous bitch [emoticon] easy babe [emoticon]

(Facebook post, female user from AMBA)

In this transcription, a teenage girl (16 years old) claims to be a victim of bullying as her name appeared on graffiti painted on the walls of the school she attends. Like many posts found on Facebook walls, these graffiti are an updated version of traditional gender roles in sexual-affective practices: Males are socially legitimized if they have and accumulate several experiences whereas, for women, often times, the same dynamic is questioned, even by fellow females. Furthermore, another possible modulation of the expressions surrounding violence can be observed: an adolescent is a victim of faceto-face bullying and she finds a way of exposing the violence she suffered on Facebook, that is, online.

Another cyberbullying-related practice recurrently observed among the adolescents included in the sample is the so-called "escrache" [public accusation intended to shame and expose someone]. Originally, this term was used by human rights associations, such as Sons and Daughters for Identity and Justice against Oblivion and Silence (HIJOS) [Hijos e Hijas por la Identidad y la Justicia contra el Olvido y el Silencio], that "escrachaban" (pinpointed, publicly identified) repressors from the last military dictatorship who had not been given a definitive sentence. Once this method became widespread, the term was adopted by many adolescents from AMBA with different meanings. It is frequently used in the phrase "escrache photo," that is, a selfie or personal picture taken by someone else that harms the reputation of the user appearing in the picture. There is also another meaning related to aggression or denouncement through Facebook.

In this context, "escrache" is a resource used to alert a peer group about a user's certain violent behaviors. Thus, it also serves as a means of empowerment used by some teenage girls of marginalized working-class areas. These types of warnings are sometimes circulated through the contact network: "Beware of $[\mathrm{X}]$ who cheats on you and cares about nothing except seducing whoever is on a chat room" (female, 17 years old). "I fell in love, but I was foolish. [X] lied to me and I believed him. It's all pick-up lines" (female, 16 years old). As observed in several examples, denouncing a male through an "escrache" usually carries a sexual-affective grief component, but also raises awareness among the women in their contact network of the sex/gender behavior of males.

As previously stated, the "escrache" practice also has an esthetic dimension when a picture is taken by someone without the permission of the person being photographed. This expression seeks to discredit or embarrass the person in the picture and, at the same time, to increase the popularity of the author of the post. The focus of the "escrache" has shifted over time: What used to be a group practice strongly founded in sociopolitical denunciation of crimes against humanity, has now turned into a practice with elements of identity, esthetics and "aguante" deeply-rooted in the neighborhood, which becomes quickly socialized through this social networking platform.

\section{Grief}

Adolescents from marginalized working-class areas often experience the death of friends, peers, or acquaintances, sometimes as a consequence of violent events Imbusch et al. (2011; Auyero and Berti, 2013). At the same time, societies have undergone a transformation in the way in which grief is dealt with. Funerary rites have changed in the last few decades and ICTs have given rise to numerous practices that include the remembrance of the deceased in social networking websites. The adolescents in the sample reappropriated these practices and resignified them in a specific context in order to preserve the memory of a deceased contact, although there are some shared components with the online actions of some adults (Ramos, 2015).

In some of the cases analyzed herein, the profile of the deceased adolescent is managed by close friends or family members. Furthermore, these practices unite the group against the otherness: Other peer groups, local criminal gangs or the police. These types of posts usually show sadness and a desire for justice over the violent episode that caused the death of a beloved one. 


\begin{abstract}
A former schoolmate was killed in a gang confrontation. I'd have liked to be his friend. I sometimes miss him. It's strange that he's no longer with us. Recently I posted something on Facebook to remember him and support his family and friends, who are suffering a lot. We experience things like this all the time. (Interview, female, 15 years old)
\end{abstract}

In one of the images studied, an adolescent (14 years old) posted a photomontage in which he overlaid a transparent-background image of his brother's face on an image of the sky, with the words "Today My Heart only Thinkz About You, Today It's 1 Year Since You're no Longer HERe and You've no idea of How Much I MISs you Little BroTher." In a similar post, an adolescent (15 years old) wrote that he used to sit beside his late classmate in primary school, that he would have liked to develop a friendship and that he cannot believe what happened to him. The posts received 65 and 92 "likes," respectively, showing the high level of acceptance that these types of commemorations have within the contact network.

These traumatic events are usually incorporated into the settings of the profiles of adolescents from marginalized working-class areas. This is something they take into account even when looking for new sexual-affective bonds, because they perceive the abandonment of the mourning and the failure to mention them periodically on their biography as treason or lack of "aguante." Occasionally, a commemoration is added to the cover photo or the name of the profile ("Forever Maxi;" "I miss you, Ranchi"). Contacts who are not so close to the deceased usually leave "likes" and comments as gestures of support for the deceased's acquaintances. Furthermore, it is common to find demands and requests for justice for the death of adolescents in unclear circumstances (criminal acts, "score-settling," "trigger-happy shootings").

\section{A few years ago one of my best friends died. The neighborhood is not safe, but we all watch out for each other. Every now and then the police search us and sometimes beat us because they think we did something wrong just because we are from the neighborhood, who knows. [...] Sometimes we share things on Facebook about him just to remember him and support his family and friends, who are having a rough time. (Interview, female, 16 years old)}

In these practices, posts marked by friendship, affection and grief converge as a new way of overcoming the death of beloved ones. Facebook provides a space where they can express themselves and receive feedback from their peers, giving way to interaction and, sometimes, creating a new bond or reinforcing a previous one, which may change in different ways. In this regard, more research should be done into these types of phenomena in order to understand how these adolescents resignify their subjectivities and the effect of the violence they endure.

\section{Discussion}

Among the research studies that focus on these population groups-defined here as adolescents from marginalized working-class areas-papers that examine urban violence have been revisited. The specific contribution intended by this paper is to relate these findings to the impact of ICTs and, in particular, to the rising popularity of social networking websites. Among the multiple expressions of violence obtained through the chosen methodological strategy, the scope of this paper has been limited to the analysis of those that took place on Facebook: Threats, "bondis," cyberbullying and grief.

The review of the relevant literature carried out by Valdivia and González (2014) provides evidence that threats among youths are frequent on a global scale and aggressions related to sexual-affective relationships occur in up to two thirds of the sample of youths in different latitudes. As stated by these researchers, most of the studies that deal with these problems do so by studying young undergraduates, who are more accessible because they usually attend the same institutions as the research professors. Moreover, the contribution to the field intended by this paper consists in the exploration of modulations of online relational aggressions among adolescents from marginalized areas.

Buelga and Pons (2012) argue that the frequency of cyberbullying-related events among youth varies, according to different global studies, between $5 \%$ and $34 \%$ and, as these authors suggest, the statistical variability among the various research studies makes result comparisons difficult. This is due, in part, to the lack of consensus about a definition of cyberbullying and the variables to be measured (Smith et al., 2008; Bottino et al., 2015). Ultimately, even with these limitations, it is imperative to continue doing research into the issue of cyberbullying on Facebook because, according to different studies (Menay-López and de la Fuente-Mella, 2014; Boyd, 2014), it is the most popular platform used by adolescents for cyberbullying and other expressions of online violence.

The pioneering studies about online expressions of violence among adolescents were mostly conducted in Western Europe, the US and Australia (Smith et al., 2008; Mason, 2008; Kowalski et al., 2008; Bottino et al., 2015; Price and Dalgleish, 2010). These studies were the first ones to tackle these phenomena-cyberbullying in particular-as ICTs spread faster in these countries than in 
others. However, the recent literature argues that although digital violence among adolescents is still frequent in these geographical areas (Buelga and Pons, 2012; Garaigordobil, 2011; Bottino et al., 2015), it has progressively extended to Latin America (Wendt and Lisboa, 2013; Menay-López and de la Fuente-Mella, 2014). Additionally, due to the scarcity of empirical studies in Latin America (Wendt and Lisboa, 2013; Aisenson et al., 2006) involving working-class adolescents in particular, it is necessary to intensify research in this field in light of the specific features of Latin-American societies and economies.

Why does Facebook, the iconic "like" social media platform, also accommodate violent expressions? How do marginalized working-class adolescents produce these expressions or resignify them in their specific contexts? What are the different modulations that violence expressions acquire for males and females?

Fraternity, leadership, protection, group cohesion and their own legality encompass, in that way, features of a "we, the young" that occasionally involves violent acts whose meanings should be construed in the context of the available social conditions. Against this background, there are several options: To ignore certain typical modes of being young; to reject them; to perceive them as a fatality; or to inquire into what lies behind such violence (Duschatsky, 2011) [own translation].

The research question that this paper sets out to answer is built on the intersection of several contemporary discussions in the field of social sciences. The works of Auyero et al. (2014) were specially taken into consideration, as they describe the multiple forms of face-to-face violence experienced by adolescents from socially vulnerable areas within AMBA. According to these authors, these expressions can be seen, on the walls daubed with graffiti around the neighborhoods. Similarly, on Facebook walls, posts with visual reminders of the consequences of violence are frequent. In the same vein as Duschatsky (2011), what this paper proposes is not simply to catalogue disruptive behaviors, but to explore the different ways in which these adolescents try to give meaning to their daily practices. The goal of future research should be to further question up to what extent technological tools serve to project violent practices-included in the broadest field of urban violencerelated phenomena-or to reinforce the "available social conditions Duschatsky (2011) and contribute to the empowerment of adolescents from marginalized workingclass areas to contextualize, resignify, or shift the hegemonic social meanings attributed to violence.

\section{Conclusion}

This paper explored, through a mixed method involving digital ethnography, the expressions of violence on Facebook walls posted by adolescents from marginalized working-class locations within the Metropolitan Area of Buenos Aires. Evidence indicates that online networks are embedded in their social fabric and that, in carrying out this type of ethnographic research study, they become an appropriate tool for exploring their practices. Most violent interactions take place in an offlineonline modality, because many conflicts start in an offline setting (for example, at school or in a public square) and continue on an online platform, or vice versa.

Along these lines, four types of violence found on Facebook have been analyzed: Threats, "bondis," cyberbullying and grief. Firstly, the threatening expressions, described as warnings about future violent acts, show certain tension regarding territory, good name and reputation, respect and sexual-affective bonds. Secondly, "bondis," a native term alluding to fights, provide evidence not only of a continuum of offline-online relationships, but also of the central role of the online context as a new conflict arena. Thirdly, cyberbullyingmeaning aggressive online actions against an individual user emphasizes the fact that harassment or stalking find in Facebook a specific channel to unfold. Lastly, the mourning or grief expressions that these adolescents share on Facebook describe phenomena that are typically found in this social group and open the way for exploring how the dimensions of violence they experience are resignified.

These four aspects are associated with "aguante," a sociocultural phenomenon that can have several meanings, such as "bancar" [to support fiercely and with loyalty], defend and resist. One of the exploratory dynamics identified-which is worthy of future researchis the emergence of "aguante" practices performed by women. These expressions imply new gender norms, even though these still coexist with the persistent traditionally masculine and feminine roles, which have also been taken into account. This specific phenomenon in working-class areas reveals the complexity of the "aguante" culture in the intersection between the production of contemporary masculine and feminine subjectivity.

Finally, this paper poses a question about how much the expressions under analysis are implicitly instrumental to the social network or, on the contrary, enable a significant reappropriation by the user. If "likes" are considered to be the intrinsic currency of the social network that strengthens the sense of belonging to the peer group, these expressions reveal practices of group ritualization that, apart from being interpreted as violence, should be examined in a contextualized way. According to the Royal Spanish Academy (RAE) [Real Academia Española], the adjective "violent" may be used to describe someone who "is outside their natural state, situation, or way" or to something that is "executed against the normal condition or without reason and justice." It is therefore valid to wonder whether the expressions of violence used by these adolescents are "outside" their "condition, reason and justice", or outside other type of "condition, reason and 
justice" that not only fails to fully integrate them but also, on numerous occasions, only makes them visible under the "violent" stigma.

\section{Author's Contributions}

All authors equally contributed in this work.

\section{Ethics}

This article is original and contains unpublished material. The corresponding author confirms that all of the other authors have read and approved the manuscript and no ethical issues involved.

\section{References}

Aisenson, D., S. Batlle, G. Aisenson, L. Legaspi and M. Vidondo et al., 2006. Desarrollo identitario de los jóvenes y contextos significativos: Una perspectiva desde la psicología de la orientación. Anuario Invest., 13: 81-88.

Alabarces, P. and M. Rodríguez, 2008. Resistencias y mediaciones: Estudios sobre cultura popular. Paidós, Buenos Aires.

ANDLSS, 2013. Conectar Igualdad [Internet]. Administración Nacional de la Seguridad Social, Presidencia de la Nación, Buenos Aires.

Auyero, J. and M. Berti, 2013. La violencia en los márgenes. Katz, Buenos Aires.

Auyero, J., A. Burbano de Lara and M. Berti, 2014. Uses and forms of violence among the urban poor. J. Latin Am. Stud., 46: 443-469.

DOI: $10.1017 / \mathrm{S} 0022216$ X14000698

Benjamin, W., 1991. Para una crítica de la violencia y otros ensayos. Santillana, Madrid.

Bottino, S., C. Bottino, R. Cássio, C. Regina and W. Ribeiro, 2015. Cyberbullying and adolescent mental health: Systematic review. Cadernos de Saúde Pública, 31: 463-475. DOI: 10.1590/0102-311x00036114

Boyd, D., 2014. It's complicated: The social lives of networked teens. Yale University Press, New Haven.

Buelga, S. and J. Pons, 2012. Agresiones entre adolescentes a través del teléfono móvil y de Internet. Psychosocial Intervention, 21: 91-101. DOI: $10.5093 /$ in2012v21n 1a2

Del Río Pérez, J., C.H. Sádaba Chalezquer and X. Bringué Sala, 2010. Menores y redes ¿sociales?: De la amistad al cyberbullying. Revista de Estudios de Juventud, 88: 115-129.

Di Leo, P., 2013. Cuerpos, Vulnerabilidades y Reconocimiento: Las Violencias en Las Experiencias y Sociabilidades Juveniles. In: Quiero Escribir mi Historia: Vidas de Jóvenes en Barrios Populares, Di Leo, P. and A. Camarotti (Eds.), Biblos, Buenos Aires.
Duschatsky, S., 2011. Veo veo... ¿Qué ves?: Percepciones más allá (o más acá) de la violencia. Revista CS, 2: 343-366. DOI: 10.18046/recs.i11.1575

Elizalde, S., 2015. Tiempo de chicas: Identidad, cultura y poder. Grupo Editor Universitario, Buenos Aires.

Foucault, M., 2002a. Vigilar y castigar. Siglo XXI Editores, Buenos Aires.

Foucault, M., 2002b. Historia de la sexualidad I. Siglo XXI Editores, Buenos Aires.

Garaigordobil, M., 2011. Prevalencia y consecuencias del cyberbullying: Una revisión. Int. J. Psychol. Psychol. Therapy, 11: 233-254.

Garriga Zucal, J., 2005. 'Soy Macho Porque me la Aguanto’: Etnografia de las Prácticas Violentas y la Conformación de Identidades de Género Masculino. In: Hinchadas, Alabarces, P. (Ed.), Prometeo, Buenos Aires.

Hine, C., 2012. The Internet: Understanding qualitative research. Oxford University Press, New York.

Imbusch, P., M. Misse and M. Carrión, 2011. Violence research in Latin America and the Caribbean: A literature review. Int. J. Conflict Violence, 5: 87-154.

INDEC, 2010. Censo Nacional de Población, Hogares y Viviendas. Instituto Nacional de Estadística y Censos, Buenos Aires.

Isla, A. and D. Míguez, 2011. Formations of violence in post-dictatorial contexts: Logics of confrontation between the police and the young urban poor in contemporary Argentina. Int. J. Conflict Violence, 5: 240-260.

Kessler, G. and D.S. Jóvenes, 2013. Policía y estigmatización territorial en la periferia de Buenos Aires. Espacio Abierto, 22: 221-243.

Kowalski, R., S. Limber and P. Agatston, 2008. Cyber bullying: Bullying in the digital age. Blackwell Publishing, London.

Krauskopf, D., 2007. Adolescencia y educación. Euned, San José.

Linne, J., 2014. Usos comunes de Facebook en adolescentes de distintos sectores sociales. Comunicar, 43: 189-197. DOI: 10.3916/C43-2014-19

Linne, J., 2015. Autopresentación, amistad y vínculos sexo-afectivos en sitios de redes sociales en adolescentes de sectores populares de la Ciudad de Buenos Aires. PhD Thesis, Universidad de Buenos Aires, Facultad de Ciencias Sociales.

Margulis, M., M. Urresti and H. Lewin, 2007. Familia, hábitat y sexualidad en Buenos Aires. Biblos, Buenos Aires.

Mason, K., 2008. Cyberbullying: A preliminary assessment for school personnel. Psychol. School, 45: 323-348. DOI: 10.1002/pits.20301

MDE, 2009. Plan de Finalización de Estudios Primarios y Secundarios - FINES [Internet]. Ministerio De Educación, Presidencia de la Nación, Buenos Aires. 
Menay-López, L. and H. de la Fuente-Mella, 2014. Plataformas comunicacionales del ciberbullying: Una aplicación empírica en dos colegios de la quinta región, Chile. Estudios Pedagógicos, 40: 117-133. DOI: $10.4067 /$ S0718-07052014000300007

Míguez, D., 2006. Estilos Musicales y Estamentos Sociales: Cumbia, Villa y Transgresión en La Periferia De Buenos Aires. In: Entre Santos, Cumbias y Piquetes, Míguez, D. and P. Semán (Eds.), Biblos, Buenos Aires

Misse, M., 2010. La acumulación social de la violencia en Río de Janeiro y en Brasil: Algunas reflexiones. Co-Herencia, 7: 1-19.

Morduchowicz, R., 2012. Los adolescentes y las redes sociales. FCE, Buenos Aires.

Price, M. and J. Dalgleish, 2010. Cyberbullying: Experiences, impacts and coping strategies as described by Australian young people. Youth Stud. Australia, 29: 51-59.

Ramos, H., 2015. Além-túmulo no Facebook: Vida após a morte e luto na Era Digital. Observatorio (OBS*), 9: 31-50.

Rancière, J., 1996. El desacuerdo: Política y filosofía. Nueva Visión, Buenos Aires.

Rubin, G., 1975. The Traffic in Women: Notes on the 'Political Economy' of Sex. In: Toward an Anthropology of Women, Reiter, R. (Ed.), Monthly Review Press, New York.

Semán, P. and P. Vila, 2011. Cumbia Villera: Una Narrativa de Mujeres Activadas. En: Cumbia: Nación y género en Latinoamérica, Semán, P. and P. Vila (Eds.), Buenos Aires. Gorla.

Silba, M., 2012. Vidas plebeyas: Masculinidades, resistencias y aguante entre varones jóvenes pobres del Conurbano. Papeles de Trabajo, 6: 160-176.

Sloterdijk, P., 2000. Normas para el parque humano: Una respuesta a la carta sobre el humanismo. Siruela, Madrid.

Smith, P., J. Mahdavi, M. Carvalho, S. Fisher and S. Russell et al., 2008. Cyberbullying: Its nature and impact in secondary school pupils. J. Child Psychol. Psychiatry, 49: 376-385.

DOI: 10.1111/j.1469-7610.2007.01846.x

Spinelli, H., M. Alazraqui, G. Macias, M. Zunino and J. Nadalich, 2005. Muertes violentas en la ciudad autónoma de Buenos Aires: Una mirada desde el sector salud. OPS, Buenos Aires.

Tonkonoff, S., 2014. Violencia y cultura: Reflexiones contemporáneas sobre Argentina. Clacso, Buenos Aires.

Urresti, M., 2007. De la Cultura del Aguante a la Cultura Del Reviente: Cambios en la Significación de la Corporalidad en Adolescentes y Jóvenes de Sectores Populares. In: Hábitat y Sexualidad en Buenos Aires, Margulis, M., M. Urresti and L.H. Familia (Eds.), Biblos, Buenos Aires.
Urresti, M., J. Linne and D. Basile, 2015. Conexión total: Los jóvenes y la experiencia social en la era de la comunicación digital. Grupo Editor Universitario, Buenos Aires.

Valdivia, M. and L. González, 2014. Violencia en el noviazgo y pololeo: Una actualización proyectada hacia la adolescencia. Revista Psicología, 32: 330-355.

Wacquant, L., 2007. Los condenados de la ciudad. Siglo XXI Editores, Buenos Aires.

Wendt, G. and C. Lisboa, 2013. Agressão entre pares no espaço virtual: Definições, impactos e desafios do cyberbullying. Psicol. Clínica, 25: 73-87. DOI: $10.1590 / \mathrm{S} 0103-56652013000100005$

Willard, N., 2005. An educator's guide to cyberbullying and cyberthreats [Internet].

\section{Endnotes}

a. The Metropolitan Area of Buenos Aires (AMBA) includes the City of Buenos Aires and the so-called Greater Buenos Aires area, encompassing the municipalities of Almirante Brown, Avellaneda, Berisso, Berazategui, Cañuelas, Ensenada, Escobar, Esteban Echeverría, Ezeiza, Florencio Varela, General Rodríguez, General San Martín, Hurlingham, Ituzaingó, José C. Paz, La Matanza, La Plata, Lanús, Lomas de Zamora, Malvinas Argentinas, Marcos Paz, Merlo and Moreno. According to the Argentine Institute of Statistics and Censuses (INDEC) [Instituto Nacional de Estadísticas y Censos], a third of Argentina's population lives in AMBA.

b. The "Conectar Igualdad" [Connect Equality] program was a project launched by the Argentine federal government in 2010 consisting in giving a netbook on loan to every student and teacher of state-run secondary schools in Argentina. Within this framework, some AMBA municipal governments established digital inclusion centers at which youths could use, at no cost, computers with Internet access under the guidance of technicians and teacher facilitators.

c. "Plan Fines" [Goals Plan] was a federal government initiative launched in 2008 with the aim of giving adults who had been unable to finish secondary school education the chance to complete their studies through a more flexible scheduled course (ANDLSS, 2013; MDE, 2009).

d. The population groups included in the sample understand "bardeos" as "provoking a conflict" or "harassing others," while to them, "pararse de manos" means "to defend oneself or show no fear in the face of an ensuing fight."

e. By the term "arrugar," the population in the study understands "lacking fierce loyalty." 
f. Some of the cumbia bands mentioned by the adolescents in their Facebook posts are: Alto faso, Corre guachin, El borracho, El punga, Entre rejas, Flashito Tumbero, Flor de Piedra, Jala jala, La mafia, La rama, La tiza, La yerba del mono, Mala fama, Pala ancha, Pibes Chorros, Prende la vela, Sobredosis, Supermerka2, Tinta roja, Una de kal, Vagancia and Yerba Brava. g. It should be clarified that the gender perspective presented in this paper is largely based on the notion of a "sex/gender system, (Rubin, 1975) that is, a set of dispositions by which a society transforms biological sexuality into a product of human activity, as well as on the concept of "performativity, (Semán and Vila, 2011) which posits that sex is as culturally constructed as gender and that gender performance is marked by a heteronormative matrix. 